\title{
Preservice Teachers' Comfort Levels with Technology in an Online Standalone Educational Technology Course
}

\author{
Kevin J. Graziano \\ Nevada State College \\ kevin.graziano@nsc.edu
}

\begin{abstract}
While some researchers and teacher educators recommend the integration of technology throughout a teacher preparation program, it may not be realistic for all teacher preparation programs to comply with this recommendation. A lack of training, a lack of interest from faculty, limited faculty or facilities, and/or a lack of vision from educational leaders may prevent some teacher preparation programs from successfully integrating technology throughout the curriculum. For various reasons, colleges and schools of education may rely on standalone educational technology courses. The purpose of this study was to examine technology comfort levels of preservice teachers who completed an online standalone educational technology course with pedagogy and content integrated into the course curriculum. Findings reveal there were no statistically significant mean differences between students' comfort levels using technology for personal communication and to teach academic content. The findings have implications for teacher preparation programs and teacher educators.
\end{abstract}

Keywords: online learning, self-efficacy theory, teacher preparation, technology integration.

Technology can be a powerful tool for transforming learning. It can help affirm and advance relationships between educators and students, reinvent our approaches to learning and collaboration, shrink long-standing equity and accessibility gaps, and adapt learning experiences to meet the needs of all learners....However, to realize fully the benefits of technology in our education system and provide authentic learning experiences, educators need to use technology effectively in their practice (U.S. Department of Education, Office of Educational Technology, 2017, p. 3).

The integration of technology into the curriculum can be a difficult task for some teachers (Driskell, 1999), and approaches to using technology vary among teacher preparation programs (Karaca, 2015). Technical skills and a good attitude are not enough to prepare teachers to use technology (Zhao, Pugh, Sheldon, \& Byers, 2002). Many teacher preparation programs have redesigned curricula to comply with national technology standards from professional organizations such as the Council for the Accreditation of Educator Preparation. Technology, however, still remains under-utilized by preservice teachers, (Kirschner \& Selinger, 2003) and is often taught as a standalone introductory course (Gronseth et al., 2010). As such, preservice teacher training may not reflect the reality of how teachers should use technology in the classroom (Ottenbreit-Leftwich, Glazewski, Newby, \& Ertmer, 2010).

Sutton (2011) argues, a standalone educational technology course, which has been referred to by novice teachers as a "crash course," is not sufficient and does very little to prepare preservice teachers to successfully integrate technology into instruction (p. 44). The alternative to a 
standalone introductory technology course is to have teacher educators fully integrate technology throughout the curriculum (Gronseth et al., 2010; Tondeur et al., 2011). A problem with integrating technology throughout the curriculum is that some methods faculty within teacher preparation programs are only considered experts in their content areas and are not considered experts in teaching with technology (Foulger, Buss, Wetzel, \& Lindsey, 2012), and some faculty may lack the training and interest to effectively use technology in the classroom. The expectation is that educational technology faculty in teacher preparation programs will stay abreast of the trends and opportunities in the area of instructional technology and incorporate a wide range of technology in the teaching of educational technology courses.

In the absence of consistent and proper technology training for all teacher educators and a lack of proper technology integration throughout a teacher preparation curriculum, the researcher of this study wanted to know how comfortable preservice teachers were using technology in an online standalone educational technology course. This study was inspired by Willis' (2015) research that examined self-efficacy levels of preservice teacher candidates who participated in scaffolded technology training.

\section{Review of Literature}

Researchers have published numerous articles on the usage of technology by preservice and inservice teachers. Teachers' use of technology, argues Niederhauser and Stoddart (2001), reflects their personal beliefs about instructional practices. Overall, teachers use technology for social communication with each other and their students (Doering, Lewis, Veletsianos, \& Nichols-Besel, 2008), use technology when they believe computers improve student learning (Petko, 2012), and use technology for teacher-centered activities, (Russell, Bebell, O’Dwyer, \& O’Connor, 2003) such as record keeping and internet research on instructional materials (Sutton, 2011).

Sangrà and González-Sanmamed (2010), who utilized a multiple case study methodology to study teachers' integration, use, and perceptions of information and communication technologies, concluded teachers find technology useful for gaining students' attention and transmitting information, more so than for interaction processes and expression and communication skills. Although there has been an increase in access to technology and training for teachers, "high level technology use is still low" (An \& Reigeluth, 2011-2012, p. 56), and "ultimately the decision regarding whether and how to use technology for instruction rests on the shoulders of classroom teachers” (Ertmer, 2005, p. 27).

Research suggests that enhanced teacher efficacy is a prerequisite for effective technology use and integration (Moore-Hayes, 2011), and when teachers apply technology skills in the classroom their comfort level and confidence to integrate technology into their teaching increase (Guha, 2000; Hsu, 2010; Leh, 2000). Teachers with high ability in technology integration generally integrate technology more in the classroom than those who report they have lower skill levels. Simply put, “well-trained teachers successfully integrate technology” (Hsu, 2010, p. 320). Leh (2000) adds,

Helping teachers feel comfortable, confident, and positive is as important as teaching them specific technology content. If teachers are comfortable and confident in using technology, they will be more likely to succeed in overcoming obstacles and using technology in their classrooms (p. 346).

An and Reigeluth's (2011-2012) survey research on K-12 teachers' technology beliefs, perceptions, and support needs identified perceived obstacles to creating technology-enhanced, 
learner-centered classrooms. These obstacles included a lack of technology and time, assessment, and institutional support. Other obstacles to technology integration reported by teachers include a lack of confidence with student-centered technology instruction (Sutton, 2011).

The more preservice teachers are exposed to technology during their undergraduate and graduate years the more likely they will improve their competence and comfort levels with technology (Rizza, 2000) and the more likely they will overcome obstacles to technology integration. Teacher educators who model technology in the classroom help reduce preservice teachers' anxiety with technology and reinforce interest in technology (Ertmer, 2005). "For university faculty to develop effective, student-centered, hands-on learning activities for preservice teachers in their classes, they must themselves be skilled in using the technologies” (Sutton, 2011, p. 45).

With regard to teacher preparation in higher education, Kleiner, Thomas, and Lewis (2007) surveyed teacher candidates' preparedness to use educational technology once they enter the field. Of the 1,439 four-year institutions surveyed in the United States, " $100 \%$ of institutions with teacher education programs for initial licensure reported teaching the use of internet resources and communication tools for instruction in all or some teacher education programs” (p. 6). Ninety-nine percent of institutions taught developing curriculum plans using technology to address content standards, using content specific software tools for instruction (97\%), using multimedia digital content for instruction (95\%), and using technology to access or manipulate data to guide instruction (90\%) in all or some programs (Kleiner et al., 2007).

About half (51\%) of all institutions with various types of teacher preparation programs offered three- or four-credit standalone courses in educational technology, and about a third (34\%) offered one- or two-credit standalone courses in educational technology (Kleiner et al., 2007). Additionally, Kleiner et al. (2007) reported 93\% of four-year institutions teach educational technology within methods courses. Seventy-nine percent of teacher preparation programs reported that educational technology was taught within field experiences, and $71 \%$ reported it was taught within content courses.

In a review of 19 qualitative studies that focused on strategies to prepare preservice teachers to integrate technology into their teaching, researchers argued technology integration should be infused as a systemic aspect throughout an entire program, otherwise the knowledge and skills gained from the standalone course are likely to remain isolated and unused (Tondeur et al., 2011). "Technology should be integrated throughout a teacher preparation curriculum in order to provide preservice teachers with the skills and experiences needed to apply technology to specific content areas” (Tondeur et al., 2011, p. 2).

Sutton (2011), who used an instructional case study approach to examine the preservice technology training experiences of novice teachers, agrees with Tondeur et al. (2011) and writes, preservice teachers practice using technology more when technology is integrated throughout the curriculum and are more likely to receive an array of feedback on their usage of technology from multiple faculty. Sutton's research revealed teachers lacked confidence with student-centered technology instruction because they had not had authentic experiences using technology in their teacher training programs, and "were unable to make connections between their one required technology course and the teaching theories and methods they were learning in their other courses" (Sutton, 2011, p. 43).

Knowing what the literature suggests on technology integration throughout a teacher preparation program, it is important to note that the researcher of this study teaches at an institution where educational technology is taught mainly in a standalone course. The purpose of this study 
was to examine the technology comfort levels of preservice teachers who completed an online standalone educational technology course with pedagogy and content integrated into the course curriculum.

\section{Theoretical Framework}

The theoretical framework that guided this study was self-efficacy theory. Self-efficacy, a cognitive theory, involves "people's beliefs about their capabilities to produce designated levels of performance that exercise influence over events that affect their lives” (Bandura, 1994, para. 1). Individuals who view their own abilities with high self-confidence would approach difficult tasks as challenges rather than as obstacles (Bandura, 1994).

With self-efficacy theory, individuals are more likely to engage in activities for which they posses high levels of self-efficacy and less likely to engage in activities with low levels of selfefficacy (Van der Bijl \& Shortridge-Baggett, 2002). Individuals' self-efficacy stems from four main sources: (1) mastery experiences (success at a task builds self-efficacy while failure at a task undermines one's self-efficacy); (2) physiological and emotional states (self-efficacy beliefs are influenced by one's stress, anxiety, and mood); (3) vicarious experiences (students observe others succeed at a task), and (4) social persuasion (individuals are convinced or persuaded that they have the capabilities to be successful at a task) (Bandura, 1994).

Usher and Pajares (2008) discuss students' mastery experiences as the most powerful source of self-efficacy. They write:

After students complete an academic task, they interpret and evaluate the results obtained, and judgments of competence are created or revised according to those interpretations. When they believe that their efforts have been successful, their confidence to accomplish similar or related tasks is raised; when they believe that their efforts failed to produce the effect desired, confidence to succeed in similar endeavors is diminished. Experienced mastery in a domain often has enduring effects on one's self-efficacy (p. 752).

Self-efficacy has been identified as an important barrier for teachers to overcome before they can integrate technology effectively (Ertmer \& Ottenbreit-Leftwich, 2010). Preservice teachers often have low levels of technology self-efficacy (Willis, 2015). Willis argues,

For the technology novice, new technologies may seem threatening and overwhelming, resulting in intensification of existing beliefs about their ability to master technology related tasks. Introducing candidates, who possess low levels of self-efficacy, to technology skills that are familiar or personally gratifying will help alleviate feelings of inadequacy and potential failure. Slowly building a sense of success regarding new technology skill acquisition will promote self-confidence and increase interest in further skill development (p. 3).

Koh and Frick (2009) believe the vicarious observation of faculty modeling technology enhances preservice teachers' confidence in using technology for teaching. There is a higher chance preservice teachers will have a positive outlook using technology after they are successful with challenging tasks that utilize technology in teaching (Wood, Mueller, Willoughby, Specht, \& Deyoung, 2005). The ideal method for developing teachers' technology self-efficacy would be to provide them with ongoing training and support to work successfully with computers in their classrooms (Albion, 1999).

Research suggests there is a link between computer self-efficacy of the teacher, the comfort level of the teacher regarding technology, and classroom technology integration (Tweed, 2013). 
Koh and Frick (2009) surveyed and interviewed undergraduate preservice teachers on technology skills instruction and found that classroom interactions between instructors and students can influence students' computer self-efficacy. Additionally, Evers, Brouwers, \& Tomic (2002) studied teachers' self-efficacy beliefs as they relate to new instructional practices and levels of burnout. Results indicated that teachers' self-efficacy beliefs are related to burnout levels. Teachers with strong self-efficacy beliefs were more prepared to experiment with and implement new innovative educational practices. "An individual with a high sense of teacher self-efficacy is more inclined to create a dynamic, student-centered learning environment in which students take ownership of their learning” (Swan, Wolf, \& Cano, 2011, p. 130).

When preservice teachers' comfort levels and enjoyment increase with their use of technology, motivation, effectiveness, and competence integrating technology into the curriculum should also increase (Kim \& Jang, 2015). In a review of literature on preparing teachers for technology integration, Oliver and Townsend (2013) noted teacher motivation and determination are two related variables often associated with technology integration and have been found to be the best predictors of both intrinsic and extrinsic motivation towards technology (Cullen \& Greene, 2011).

\section{Research Question}

The research question that guided this study was, after completing an online standalone educational technology course with pedagogy and content integrated into the course curriculum, are there differences in preservice teachers' comfort levels using technology for personal productivity and instructional integration? For purposes of this study, personal productivity involved the use of technology for social communication with students, faculty, and parents. Instructional integration involved the use of technology to teach academic content.

\section{Methods}

\section{Participants}

A convenience sample of 24 preservice teachers and 1 inservice teacher, referred to as students herein, participated in this study during the spring 2016 semester. All students were enrolled in Preparing Teachers to Use Technology, a required, lower division, three-credit course taught online by the researcher of this study.

The course had 18 (72\%) female students and seven (28\%) male students, including three (12\%) seniors, 15 (60\%) juniors, four (16\%) sophomore, and three (12\%) post-baccalaureate students. Students’ majors included 13 (52\%) elementary education majors, eight (32\%) speech language pathology majors, three (12\%) secondary education majors, and one (4\%) undeclared major. Seventeen (76\%) of the students had a substitute license, and one (4\%) student was an inservice teacher.

\section{Course Context}


Preparing Teachers to Use Technology is offered every semester online via Canvas, the learning management system used by the college. It is the only required technology course education majors must complete prior to graduation. The course contained 15 modules. Students completed one module per week throughout the 15-week semester. Each module contained objectives; course resources such as videos, podcasts, PowerPoint and screencast lectures and tutorials; assignments with rubrics; and a link to the discussion board.

Students not only learned skills associated with the technology but also created an activity or lesson plan in each module that integrated technology, pedagogy, and content. For example, when students studied Google Earth, they created an activity or lesson plan that utilized Google Earth. Since the majority of students were juniors $(\mathrm{N}=15,60 \%)$, they relied on their content area courses to create activities and write lesson plans each week. Students posted all assignments to Canvas for others to view and discuss.

There was no required textbook for the course. Students read various technology related articles from the internet, viewed YouTube videos, and listened to podcasts. Before students utilized technology in the course, they read and discussed the International Society for Technology in Education standards, the Substitution, Augmentation, Modification, and Redefinition model (a model designed by Ruben Puentedura to help educators infuse technology into teaching and learning; see http://www.hippasus.com/rrpweblog/), constructivist approaches to teaching with technology, and the Universal Design for Learning (Meyer, Rose, \& Gordon, 2014).

Educational technology studied and utilized in the course included: tools for creating audio and video files, slideshow presentation tools, WebQuests, screen capture software, gaming, concept maps, word clouds, avatars, Google Earth, polling and survey tools, social media, Smart Board, and website development tools. Students downloaded free versions of the technology onto their personal computers or mobile devices. If students did not want to download the necessary technology to complete course assignments, they used computers in the Teaching and Learning Center on campus, which had the available technology on all computers.

\section{Data Collection and Data Analysis}

Students completed a survey at the end of the semester, which assessed their comfort levels using technology in the standalone educational technology course. The survey was distributed to students in Canvas and did not collect identifying information. Students received email reminders at the end of the semester that encouraged them to complete the survey. Participation in the study was voluntary and had no effect on students' final grade in the course.

The survey, created in Google Forms, contained an equal number of items that addressed two subscales: (1) participants' comfort levels using technology studied in class for personal productivity, and (2) participants' comfort levels using the same technology for instructional integration. The survey contained 30 total items rated on a 5-point Likert scale $(1=$ Not comfortable at all, 2 = Somewhat comfortable, $3=$ Neutral, $4=$ Comfortable, 5 = Very comfortable). Two outside reviewers with expertise in educational technology reviewed the survey. Minor modifications based on the reviewers' feedback were made to the survey before it was distributed. Cronbach's alpha $(\alpha)$ for the survey was .944. An acceptable alpha value should be above 70 (DeVellis, 2003). There was no pilot test of the survey.

Data from the research question were analyzed using descriptive statistics to calculate means, standard deviations, and percentages. A paired samples $t$ test assessed whether there was a statistically significant mean difference between students’ comfort levels using technology for 
personal communication and instructional integration. Data were managed and analyzed in Excel and the Statistical Package for the Social Sciences.

\section{Findings}

Twenty-five out of 30 students enrolled in the course completed the survey online. Students reported high comfort levels with five technology items studied in the course. They included: (1) word clouds (Tagxedo), (2) Google Earth, (3) online polls (Poll Everywhere), (4) online surveys (Survey Monkey), and (5) social media (Pinterest). In four of the five technology items, Tagxedo $(\mathrm{M}=4.52, \mathrm{SD}=.71)$, Google Earth $(\mathrm{M}=4.56, \mathrm{SD}=.65)$, Poll Everywhere $(\mathrm{M}=4.8, \mathrm{SD}=.58)$, and Survey Monkey $(\mathrm{M}=4.76, \mathrm{SD}=.60)$, students reported higher mean scores for feeling comfortable using the technology for instructional integration rather than for personal communication (see Table 1). In the fifth item, Pinterest, students reported the same comfort level for creating Pinterest boards for personal communication and instructional integration $(\mathrm{M}=4.68$, $\mathrm{SD}=.69)$.

A paired samples $t$ test assessed whether there was a statistically significant mean difference between students' highest comfort levels using technology for personal communication and instructional integration. Table 1 provides the numerical data. Findings revealed there was no statistically significant mean difference between students' highest comfort levels with technology for personal communication and instructional integration.

\section{Table 1. Paired samples t-test results for highest comfort levels with technology}

\begin{tabular}{|l|c|c|c|c|c|c|}
\hline Survey Item & $M$ & $S D$ & $\begin{array}{c}\text { Mean } \\
\text { Difference }\end{array}$ & $t$ & df & $p$ \\
\hline $\begin{array}{l}\text { How comfortable are you } \\
\text { creating Tagxedo word } \\
\text { clouds for personal } \\
\text { communication? }\end{array}$ & 4.48 & .77 & .04 & -1.0 & 24 & .327 \\
\hline $\begin{array}{l}\text { How comfortable are you } \\
\text { creating Tagxedo word } \\
\text { clouds to teach academic } \\
\text { content? }\end{array}$ & 4.52 & .71 & & & & \\
\hline $\begin{array}{l}\text { How comfortable are you } \\
\text { creating Google Earth } \\
\text { material for personal } \\
\text { communication? }\end{array}$ & 4.44 & .82 & .12 & -1.81 & 24 & .083 \\
\hline $\begin{array}{l}\text { How comfortable are you } \\
\text { creating Google Earth } \\
\text { material to teach academic } \\
\text { content? }\end{array}$ & 4.56 & .65 & & & & \\
\hline $\begin{array}{l}\text { How comfortable are you } \\
\text { creating Poll Everywhere } \\
\text { polls for personal } \\
\text { communication? }\end{array}$ & 4.68 & .69 & .12 & -1.37 & 24 & .185 \\
\hline
\end{tabular}




\begin{tabular}{|c|c|c|c|c|c|c|}
\hline $\begin{array}{l}\text { How comfortable are you } \\
\text { creating Poll Everywhere } \\
\text { polls to teach academic } \\
\text { content? }\end{array}$ & 4.8 & .58 & & & & \\
\hline $\begin{array}{l}\text { How comfortable are you } \\
\text { creating Survey Monkey } \\
\text { surveys for personal } \\
\text { communication? }\end{array}$ & 4.64 & .70 & .12 & -1.37 & 24 & .185 \\
\hline $\begin{array}{l}\text { How comfortable are you } \\
\text { creating Survey Monkey } \\
\text { surveys to teach academic } \\
\text { content? }\end{array}$ & 4.76 & .60 & & & & \\
\hline $\begin{array}{l}\text { How comfortable are you } \\
\text { creating Pinterest boards for } \\
\text { personal communication? }\end{array}$ & 4.68 & .69 & 0 & & & 1 \\
\hline $\begin{array}{l}\text { How comfortable are you } \\
\text { creating Pinterest boards to } \\
\text { teach academic content? }\end{array}$ & 4.68 & .69 & & & & \\
\hline
\end{tabular}

Note. Statistically significant $(\mathrm{p}<.05)$

Students reported moderate comfort levels with seven technology items studied in the course. They included: (1) creating slideshows (Animoto), (2) WebQuests, (3) screen capture files (Jing), (4) concept maps (Inspiration), (5) avatars (GoAnimate and Voki), (6) Smartboard, and (7) creating websites (Weebly and Wix). Students who created activities and lesson plans with avatars had characters tell stories, explain how to solve a math problem, recited instructions to an assignment, and used them with English language learners to listen to English.

With the exception of creating slide shows, students reported higher comfort levels creating WebQuests $(\mathrm{M}=4.32$, SD $=.75)$, screen capture files (Jing) $(\mathrm{M}=4.32$, SD = .95), concept maps (Inspiration) $(\mathrm{M}=4.24, \mathrm{SD}=.83)$, avatars (GoAnimate or Voki) $(\mathrm{M}=4.04$, $\mathrm{SD}=.98)$, Smart Boards $(\mathrm{M}=4.16, \mathrm{SD}=.80)$, and website builders (Weebly or Wix) $(\mathrm{M}=4.32, \mathrm{SD}=.80)$ for instructional integration rather than using the same technology for personal communication.

A paired samples $t$ test assessed whether there was a statistically significant mean difference between students' moderate comfort levels using technology for personal communication and instructional integration. Table 2 provides the numerical data. Findings revealed there was no statistically significant mean difference between students' moderate comfort levels with technology for personal communication and instructional integration.

Table 2. Paired samples t-test results for moderate comfort levels with technology

\begin{tabular}{|l|c|c|c|c|c|c|}
\hline Survey Item & $M$ & $S D$ & $\begin{array}{c}\text { Mean } \\
\text { Difference }\end{array}$ & $t$ & df & $p$ \\
\hline $\begin{array}{l}\text { How comfortable are you creating } \\
\text { Animoto slideshow presentations for } \\
\text { personal communication? }\end{array}$ & 4.24 & .93 & .12 & 1.37 & 24 & .185 \\
\hline
\end{tabular}




\begin{tabular}{|c|c|c|c|c|c|c|}
\hline $\begin{array}{l}\text { How comfortable are you creating } \\
\text { Animoto slideshow presentations to teach } \\
\text { academic content? }\end{array}$ & 4.12 & .93 & & & & \\
\hline $\begin{array}{l}\text { How comfortable are you creating } \\
\text { WebQuests for personal communication? }\end{array}$ & 4.28 & .89 & .04 & -.272 & 24 & .788 \\
\hline $\begin{array}{l}\text { How comfortable are you creating } \\
\text { WebQuests to teach academic content? }\end{array}$ & 4.32 & .75 & & & & \\
\hline $\begin{array}{l}\text { How comfortable are you creating Jing } \\
\text { screen capture files for personal } \\
\text { communication? }\end{array}$ & 4.24 & .97 & .08 & -1.45 & 24 & .161 \\
\hline $\begin{array}{l}\text { How comfortable are you creating Jing } \\
\text { screen capture files to teach academic } \\
\text { content? }\end{array}$ & 4.32 & .95 & & & & \\
\hline $\begin{array}{l}\text { How comfortable are you creating } \\
\text { Inspiration concept maps for personal } \\
\text { communication? }\end{array}$ & 4.2 & .87 & .04 & -1.0 & 24 & .377 \\
\hline $\begin{array}{l}\text { How comfortable are you creating } \\
\text { Inspiration concept maps to teach } \\
\text { academic content? }\end{array}$ & 4.24 & .83 & & & & \\
\hline $\begin{array}{l}\text { How comfortable are you creating } \\
\text { GoAnimate or Voki avatars for personal } \\
\text { communication? }\end{array}$ & 4.0 & .96 & .04 & -.569 & 24 & .574 \\
\hline $\begin{array}{l}\text { How comfortable are you creating } \\
\text { GoAnimate or Voki avatars to teach } \\
\text { academic content? }\end{array}$ & 4.04 & .98 & & & & \\
\hline $\begin{array}{l}\text { How comfortable are you creating Smart } \\
\text { Board material for personal } \\
\text { communication? }\end{array}$ & 4.08 & .81 & .08 & -.811 & 24 & .425 \\
\hline $\begin{array}{l}\text { How comfortable are you creating Smart } \\
\text { Board material to teach academic } \\
\text { content? }\end{array}$ & 4.16 & .80 & & & & \\
\hline $\begin{array}{l}\text { How comfortable are you creating } \\
\text { Weebly or Wix websites for personal } \\
\text { communication? }\end{array}$ & 4.28 & .84 & .04 & -.569 & 24 & .574 \\
\hline $\begin{array}{l}\text { How comfortable are you creating } \\
\text { Weebly or Wix websites to teach } \\
\text { academic content? }\end{array}$ & 4.32 & .80 & & & & \\
\hline
\end{tabular}

Note. Statistically significant $(\mathrm{p}<.05)$

Students reported relatively low comfort levels with three technology items studied in the course. They included: (1) creating audio files, (2) creating video files, and (3) using gaming material. In contrast to data from the technology with the highest comfort levels, students reported slightly higher mean scores for feeling comfortable creating audio $(\mathrm{M}=3.96, \mathrm{SD}=.93)$ and video $(\mathrm{M}=3.68, \mathrm{SD}=1.03)$ files for personal communication rather than creating audio $(\mathrm{M}=3.8$, SD $=.96)$ and video $(\mathrm{M}=3.6, \mathrm{SD}=.96)$ files to teach academic content. The mean scores for using gaming material for personal communication and instructional integration were 3.88 (SD = 1.05) 
and $3.92(\mathrm{SD}=1.04)$ respectively.

A paired samples $t$ test assessed whether there was a statistically significant mean difference between students' lowest comfort levels using technology for personal communication and to teach academic content. Table 3 provides the numerical data. Findings revealed there was no statistically significant mean difference between students' lowest comfort levels with technology for personal communication and the teaching of academic content.

Table 3. Paired samples t-tests results for lowest comfort levels with technology

\begin{tabular}{|l|c|c|c|c|c|c|}
\hline Survey Item & $M$ & $S D$ & $\begin{array}{c}\text { Mean } \\
\text { Difference }\end{array}$ & $t$ & df & $p$ \\
\hline $\begin{array}{l}\text { How comfortable are you creating } \\
\text { audio files for personal } \\
\text { communication? }\end{array}$ & 3.96 & .93 & .16 & .641 & 24 & .527 \\
\hline $\begin{array}{l}\text { How comfortable are you creating } \\
\text { audio files to teach academic content? }\end{array}$ & 3.8 & .96 & & & & \\
\hline $\begin{array}{l}\text { How comfortable are you creating } \\
\text { video files for personal } \\
\text { communication? }\end{array}$ & 3.68 & 1.03 & .08 & .385 & 24 & .703 \\
\hline $\begin{array}{l}\text { How comfortable are you creating } \\
\text { video files to teach academic content? }\end{array}$ & 3.6 & .96 & & & & \\
\hline $\begin{array}{l}\text { How comfortable are you using } \\
\text { gaming material for personal } \\
\text { communication? }\end{array}$ & 3.88 & 1.05 & .04 & .440 & 24 & .664 \\
\hline $\begin{array}{l}\text { How comfortable are you using } \\
\text { gaming material to teach academic } \\
\text { content? }\end{array}$ & 3.92 & 1.04 & & \multicolumn{3}{|}{} \\
\hline
\end{tabular}

Note. Statistically significant $(\mathrm{p}<.05)$

\section{Discussion}

The purpose of this study was to examine technology comfort levels of preservice teachers who completed an online standalone educational technology course with pedagogy and content integrated into the course curriculum. Students, overall, reported being comfortable using technology for personal communication and teaching academic content when pedagogy and content were integrated into the curriculum. However, data from the paired samples $t$ tests indicated there were no statistically significant mean differences between students' comfort levels using technology for personal communication and instructional integration. The use of gaming, and the creation of audio and video files were associated with lower comfort levels, suggesting that students preferred to use these items for personal communication.

Given the use of social media, smart phones, and mobile devices that allow users to create audio and video files, it was a surprise that students reported lower comfort levels creating audio and video files for both personal communication (audio $M=3.96$; video $M=3.68$ ) and instructional integration (audio $\mathrm{M}=3.8$; video $\mathrm{M}=3.6$ ). It is unknown whether students had difficulty with the technology to create the files, did not understand when to use audio and video for personal communication and instructional integration, or simply had concerns and anxiety 
listening to their recorded voice or viewing themselves on video.

It is important to keep in mind that self-efficacy beliefs are informed by emotional and physiological states. Feelings of stress and anxiety can have a negative impact on teacher-efficacy levels for technology integration (Moore-Hayes, 2011) because such feelings translate to a lack of control and general threats to task achievement (Tweed, 2013). Students learn to interpret their physiological arousal as an indicator of personal competence by evaluating their own performances under differing conditions (Usher \& Pajares, 2008).

Students will likely have access to their own mobile devices and technology that will allow them to record audio and video when they become teachers; therefore, it is important for educators and researchers to understand students' concerns with these items. Virtual learning environments including flipped instruction (Graziano, 2017; Graziano \& Hall, 2017) and online teaching (Graziano \& Feher, 2016) require teachers to utilize a variety of technology including the creation of podcasts, screencasts, and videos. Since self-efficacy beliefs are most likely to change during skill development when individuals are faced with novel tasks (Usher \& Pajares, 2008), teacher educators should include audio and video technology in their technology courses so preservice teachers can continuously explore them with comfort and ease.

Students also reported lower comfort levels using gaming materials for both personal communication $(\mathrm{M}=3.88)$ and instructional integration $(\mathrm{M}=3.92)$. Students reported slightly higher comfort scores using avatars for personal communication $(\mathrm{M}=4.0)$ and instructional integration $(\mathrm{M}=4.04)$. It is unclear whether students connected the use of avatars to gaming. Teachers' low motivation and lack of confidence in using new technologies can influence their level of engagement in using technology for pedagogical purposes (Balanskat, Blamire, \& Kefala, 2006), which may have been the case with students' use of gaming in this study.

More and more educational software today involves gaming. Allan (2010) believes a video game self-efficacy scale could be used by teachers for struggling students who lack academic selfefficacy, but have a great deal of video game self-efficacy. Theoretically, Allan argues, "a teacher could use a student's high self-efficacy beliefs for playing video games to build up self-efficacy in other areas such as math, reading, and writing” (p. 5). Teacher educators should consider ways to foster the development of academic self-efficacy through gaming in teacher preparation courses.

Students reported the highest comfort levels using word clouds, social media (Pinterest), Google Earth, and polling and survey tools for both personal communication and instructional integration. Access and usage of other social media sites outside of class may have increased their interest and comfort levels with Pinterest. Students created multiple surveys and polls in the course and analyzed results from their surveys. This may have contributed to their high comfort levels creating surveys and polls. Additionally, students studied Google Earth by creating individual virtual field trips overseas to towns where their ancestors resided. The assignment was authentic and personal, which may have contributed to their interest and comfort using Google Earth. Exposure to authentic and successful technology integration during teacher training can assist new teachers with the inclusion of technology as part of a teaching strategy (Moore-Hayes, 2011).

Students shared all of their assignments with their peers enrolled in the course, and received constructive feedback on every assignment from the instructor. Research suggests that encouragement from teachers and peers whom students trust can boost students' confidence in their academic capabilities (Usher \& Pajares, 2008). "When they are not yet skilled at making accurate self-appraisals, students often depend on others to provide evaluative feedback and judgments about their academic performance. Supportive messages can serve to bolster a student's effort and self-confidence” (Usher \& Pajares, 2008, p. 754). It is unclear whether or not the 
encouragement students received throughout the course had an effect on their technology selfefficacy skills. Further research is needed on the use of teacher educators' verbal and social persuasions and its effect on preservice teachers' technology self-efficacy beliefs.

Although students, overall, reported moderate to high comfort levels using technology for both personal communication and instructional integration, students' self-reported confidence scores in using technology with instruction were -on almost every item-very similar to their selfreported confidence scores in using technology for personal communication. This would suggest students may not have had a deep understanding of how to truly integrate technology throughout the curriculum even though the course allowed students to not only demonstrate proficiency with the technology but also design activities and lesson plans that integrated technology with content.

It should be noted that it is not unusual in the state where this study occurred for $76 \%$ (N $=17$ ) of the students to have a substitute teacher license. There is an ongoing teacher shortage in the state, and students are encouraged by some teacher preparation faculty to obtain a substitute license. It is unknown whether students simply obtained a substitute license to include in their professional portfolio or had actual classroom experience as substitutes. If the students with a substitute license were active "subs" in the classroom, they would have had some "teaching" experience to draw on to integrate technology successfully into their curriculum. Further research is needed to measure preservice teachers' substitute teaching experiences and their technology integration in the classroom. All preservice teachers should have multiple opportunities to increase their self-efficacy as teachers, and to observe, practice, and reflect on student-centered technologyenriched lessons (Sutton, 2011).

\section{Implications for Teacher Preparation}

According to the 2017 National Technology Education Plan,

Teachers need to leave their teacher preparation programs with a solid understanding of how to use technology to support learning. Effective use of technology is not an optional add-on or a skill that teachers pick up once they get into the classroom.... No new teacher exiting a teacher preparation program should require remediation by his or her hiring school or district. Instead, every new teacher should be prepared to model how to select and use appropriate technology to support learning. It is inaccurate to assume that because preservice teachers are tech savvy in their personal lives they will understand how to use technology effectively to support learning without specific training and practice (U.S. Department of Education, Office of Educational Technology, 2017, p. 3536).

Being able to use technology does not mean one is able to use it critically, wisely, and meaningfully (Lei, 2009). If teacher preparation programs offer a standalone educational technology course, it is recommended that faculty embed technology, pedagogy and content into the curriculum rather than only focus on technology proficiency skills. When the focus of a standalone educational technology course moves beyond technology skill proficiency alone and includes pedagogy and content, students have diverse opportunities to integrate technology into practice. Ongoing professional development that utilizes current approaches to empowering teaching with technology can also be an effective means of increasing efficacy levels for technology integration (Moore-Hayes, 2011).

Teacher preparation programs should collaborate with school districts and policymakers to design professional learning opportunities for teachers that are aligned with technology state 
standards (U.S. Department of Education, Office of Educational Technology, 2017). Since access to technology and the approaches teachers take to integrate technology into the curriculum vary among schools, one such professional learning opportunity may include preservice teachers completing field experiences in multiple school settings. "This will allow them to realize the possibilities, roadblocks, and facilitating aspects, including technology and personnel resources, that may be required [as teachers]" (Foulger et al., 2012, p. 56). Integrating field experiences into technology courses would also allow preservice teachers to teach technology-infused lessons in the classroom and build self-efficacy skills. This would allow teacher educators, cooperating teachers, and/or classroom supervisors to observe preservice teachers and provide critical feedback. "If teachers can practice using technology in the classroom, they may be more likely to overcome barriers when using technology in their own classrooms” (Gronseth et al., 2010, p. 34).

\section{Limitations}

There were a few limitations to this study. The number of participants in this study was low $(\mathrm{N}=$ 25); therefore, the findings should not be generalized. Although students informally disclosed at the beginning of the semester through posts in Canvas that they were unfamiliar with the list of technology used in this study, there was no pre-survey administered to assess students' comfort levels using technology. This study relied soley on post-survey data. The use of post-survey data from one section of an online standalone educational technology course contributes to the literature on the development and outcome of standalone educational technology courses, but it is not sufficient to explore students' technology self-efficacy skills and the adequacy of students' preparation to fully integrate technology into the curriculum.

While students were required to study technology theory and develop technology rich lessons, students were not observed teaching their lessons in the classroom and were not observed using the technology skills they acquired from class. Additionally, it is unknown if Preparing Teachers to Use Technology was the first online course students completed, and what effect navigating around Canvas while simultaneuously learning new technology without an instructor "present" had on students.

Another limitation to this study was the list of technology items studied in the course. It was not an exhaustive list of technology that teachers use in the classroom. Other technology not studied in class but used by students outside of class may have affected students' technology selfefficacy skills for personal communication and instructional integration. Finally, survey research consists of self-reported behavior rather than observable behavior and may be suspectible to bias (Archambault, 2011).

\section{Conclusion}

Content in a standalone educational technology course whether offered online or on-campus should not be limited to technology skill proficiency alone. For many preservice teachers, they only complete one technology course in their licensure program (Gronseth et al., 2010). This 
course should maximize opportunities for preservice teachers to increase their self-efficacy using technology and understand the interplay between technology, pedagogy, and content. Zhao et al. (2002) report, "successful implementation of classroom technology is more likely to occur when teachers viewed technology as a means to an end, rather than an end itself, and when they see an intimate connection between technology and the curriculum” (p. 492).

Teacher educators and teacher education administrators should become familiar with technology standards and, as Sutton (2011) explains, be prepared to think differently about technology and adjust their own behavior. A change process may be challenging and difficult for teacher educators and administrators, but the benefits of modeling effective use of technology and developing technology-ready preservice teachers, whether in a standalone course or throughout the curriculum, may outweigh the challenges.

\section{References}

Albion, P. R. (1999). Self-efficacy beliefs as an indicator of teachers' preparedness for teaching with technology. In J. Price, J. Willis, D. Willis, M. Jost \& S. Boger-Mehall (Eds.), Proceedings of Society for Information Technology \& Teacher Education International Conference (pp. 1602-1608). Chesapeake, VA: Association for the Advancement of Computing in Education (AACE).

Allan, J. D. (2010). An introduction to video game self-efficacy. Masters of Arts in Psychology Thesis. California State University: Chico.

An, Y., J. \& Reigeluth, C. (2011-2012). Creating technology enhanced, learner-centered classrooms: K-12 teachers' beliefs, perceptions, barriers, and support needs. Journal of Digital Learning in Teacher Education, 28(2), 54-62.

Archambault, L. (2011). The practitioner's perspective on teacher education: Preparing for the K-12 online classroom. Journal of Technology and Teacher Education, 19(1), 73-91.

Balanskat, A., Blamire, R., \& Kefala, S. (2006). The ICT impact report: A review of studies of ICT impact on schools in Europe. Retrieved from https://ictedupolicy.org/fr/content/ict-impactreport-review-studies-ict-impact-schools-europe - sthash.sjHlPnaz.dpuf.

Bandura, A. (1994). Self-efficacy. In Encyclopedia of Human Behavior, 4, V. S. Ramachaudran (Ed.), New York: Academic Press, 71-81.

Cullen, T. A. \& Greene, B. A. (2011). Preservice teachers’ beliefs, attitudes, and motivation about technology integration. Journal of Educational Computing Research, 45(1), 29-47.

DeVellis, R. F. (2003). Scale development: Theory and applications (2nd ed.) Thousand Oaks, California: Sage.

Doering, A., Lewis, C., Veletsianos, G., \& Nichols-Besel, K. (2008). Preservice teachers' perceptions of instant messages in two educational contexts. Journal of Computing in Teacher Education, 25(1), 5-12. 
Driskell, T. L. (1999). The design and development of HELPER, a constructivist lesson plan Web resource to model technology integration for teachers. Ph.D. thesis, University of Houston.

Ertmer, P. A. (2005). Teacher pedagogical beliefs: The final frontier in our quest for technology integration? Educational Technology Research \& Development, 53(4), 25-39.

Ertmer, P. A., \& Ottenbreit-Leftwich, A. T. (2010). Teacher technology change: How knowledge, confidence, beliefs, and culture intersect. Journal of Research on Technology in Education, 42(3), 255-284.

Evers, W. J. G., Brouwers, A., \& Tomic, W. (2002). Burnout and self-efficacy: A study on teachers' beliefs when implementing an innovative educational system in the Netherlands. British Journal of Educational Psychology, 72(2), 227-243.

Foulger, T. S., Buss, R. R., Wetzel, K., \& Lindsey, L. (2012). Preservice teacher education benchmarking a standalone ed tech course in preparation for change. Journal of Digital Learning in Teacher Education, 29(2), 48-58.

Graziano, K. J. (2017). Peer teaching in a flipped teacher education classroom. TechTrends, 61(2), 121-129.

Graziano, K. J. \& Hall, J. D. (2017). Flipped instruction with English language learners at a newcomer high school. Journal of Online Learning Research, 3(2),175-196.

Graziano, K. J., \& Feher, L. (2016). A dual placement approach to online student teaching. Contemporary Issues in Technology and Teacher Education Journal, 16(4), 495-513.

Gronseth, S., Brush, T., Ottenbreit-Leftwich, A., Strycker, J., Abaci, S., Easterling, W., Roman, T., Shin, S., \& van Leusen, P. (2010). Equipping the next generation of teachers: Technology preparation and practice. Journal of Digital Learning in Teacher Education, 27(1), 30-36.

Guha, S. (2000). Digital linkage: Factors related to elementary grade teachers' usage of computers in classroom instruction. Paper presented at the Meeting of the Research Association for Minority Professors, Houston, TX. (ERIC Document Reproduction Service No. ED 438936.)

Hsu, S. (2010). The relationship between teachers' technology integration ability and usage. Journal of Educational Computing Research, 43(3), 309-325.

Karaca, F. (2015). An investigation of preservice teachers' technological pedagogical content knowledge based on a variety of characteristics. International Journal of Higher Education, 4(4), 128-136.

Kim, H. J. \& Jang, H. Y. (2015). Motivating pre-service teachers in technology integration of web 2.0 for teaching internships. International Education Studies, 8(8), 21-32. 
Kirschner, P. \& Selinger, M. (2003). The state of affairs of teacher education with respect to information and communications technology. Technology, Pedagogy, and Education, 12(1), 5-18.

Kleiner, B., Thomas, N., \& Lewis, L. (2007). Educational technology in teacher education programs for initial licensure (NCES 2008-040). Washington, DC: National Center for Education Statistics, Institute of Education Sciences, U.S. Department of Education.

Koh, J., \& Frick, T. (2009). Instructor and student classroom interactions during technology skills instruction for facilitating preservice teachers' computer self-efficacy. Journal of Educational Computing Research, 40(2), 221-228.

Leh, A. S. C. (2000). Teachers' comfort level, confidence, and attitude toward technology at a technology course. In D. Willis, J. Price \& J. Willis (Eds.), Proceedings of Society for Information Technology \& Teacher Education International Conference (pp. 343-347). Chesapeake, VA: Association for the Advancement of Computing in Education (AACE).

Lei, J. (2009). Digital natives as preservice teachers: What technology preparation is needed? Journal of Computing in Teacher Education, 25(3), 87-97.

Meyer, A., Rose, D. H., \& Gordon, D. (2014). Universal design for learning: Theory and practice. Wakefield, MA: CAST Professional Publishing.

Moore-Hayes, C. (2011). Technology integration preparedness and its influence on teacherefficacy. Canadian Journal of Learning and Technology, 37(3), 1-15.

Niederhauser, D. S. \& Stoddart, T. (2001). Teachers’ instructional perspectives and use of educational software. Teaching and Teacher Education, 17, 15-31.

Oliver, K. \& Townsend L. (2013). Preparing teacher for technology integration: Programs, competencies, and factors from the literature. National Teacher Education Journal, 6(3), 41-60.

Ottenbreit-Leftwich, A. T., Glazewski, K. D., Newby, T. J., \& Ertmer, P. A. (2010). Teacher value beliefs associated with using technology: Addressing professional and student needs. Computers \& Education, 55(3), 1321-1335.

Petko, D. (2012). Teachers' pedagogical beliefs and their use of digital media in classrooms: Sharpening the focus of the 'will, skill, tool' model and integrating teachers constructivist orientations. Computers \& Education, 58(4), 1351-1359.

Rizza, M. G. (2000). Perspectives on preservice teachers' attitudes towards technology. The Teacher Educator, 36(2), 132-147.

Russell, M., Bebell, D., O’Dwyer, L., \& O’Connor, K. (2003). Examining teacher technology use: Implications for preservice and inservice teacher preparation. Journal of Teacher Education, 54(4), 297-310. 
Sangrà, A., \& González-Sanmamed, M. (2010). The role of information and communication technologies in improving teaching and learning processes in primary and secondary schools. Research in Learning Technology, 18(3), 207-220.

Sutton, S. R. (2011). The preservice technology training experience of novice teachers. Journal of Digital Learning in Teacher Education, 28(1), 39-47.

Swan, B. G., Wolf, K. J., \& Cano, J. (2011). Changes in teacher self-efficacy from the student teaching experience through the third year of teaching. Journal of Agricultural Education, 52(2), 128-139.

Tondeur, J., van Braak, J., Sang, G., Voogt, J., Fisser, P., \& Ottenbreit-Leftwich, A. (2011). Preparing preservice teachers to integrate technology in education: A synthesis of qualitative evidence. Computers \& Education, 59(1), 134-144.

Tweed, S. R. (2013). Technology implementation: Teacher age, experience, self-efficacy, and professional development as related to classroom technology integration. Electronic Theses and Dissertations. Paper 1109. Retrieved from http://dc.etsu.edu/etd/1109.

U.S. Department of Education, Office of Educational Technology (2017). Reimagining the role of technology in education: 2017 national education technology plan update. Retrieved from https://tech.ed.gov/files/2017/01/NETP17.pdf.

Usher, E., \& Pajares, F. (2008). Sources of self-efficacy: Critical review of the literature and future directions. Review of Educational Research, 78(4), 751-796.

Van der Bijl, J. J. \& Shortridge-Baggett, L. M. (2002). The theory and measurement of the self-efficacy construct. In E. A. Lentz \& L. M. Shortridge-Baggett (Eds.), Self-efficacy in nursing: Research and measurement perspectives (pp. 9-28). New York: Springer.

Willis, J. M. (2015). Examining technology and teaching efficacy of preservice teacher candidates: A deliberate course design model. Current Issues in Education, 18(3) 1-17.

Wood, E., Mueller, J., Willoughby, T., Specht, J., \& Deyoung, T. (2005). Teacher's perceptions: Barriers and supports to using technology in the classroom. Education, Communication \& Information, 5(2), 183-206.

Zhao, Y., Pugh, K., Sheldon, S., \& Byers, J. L. (2002). Conditions for classroom technology innovations. Teachers College Record, 104(3), 482-515. 